\title{
KEEFEKTIFAN TEKNIK SELF INSTRUCTION UNTUK MEREDUKSI PERILAKU KECANDUAN MEDIA SOSIAL PADA MAHASISWA FKIP UNIVERSITAS SLAMET RIYADI SURAKARTA
}

\author{
Ahmad Jawandi Eko Adi Putro, Ferisa Prasetyaning Utami \\ Universitas Slamet Riyadi \\ Email: ahmadjawandi@unisri.ac.id
}

\begin{abstract}
Abstrak
Keberadaan internet khususnya jejaring sosial telah mampu menjadikan dunia sebagai small village (desa kecil) yang melampaui batas-batas jarak dan waktu. Media sosial yang digunakan secara berlebihan dan menimbulkan kecanduan akan berdampak negatif bagi perkembangan remaja. Alternatif solusi yang bisa dilakukan dalam mereduksi kecanduan media social adalah dengan menggunakan pendekatan secara kognitif dan perilaku melalui teknik Self Instruction. Tujuan utama dalam penelitian ini adalah untuk mereduksi kecanduan media sosial pada mahasiswa melalui teknik teknik self instruction. Metode penelitan menggunakan eksperimen dengan rancangan nonequivalent group pretest-postest control design. Populasi penelitian adalah mahasiswa FKIP UNISRI, sedangkan pengambilan sampel menggunakan purposive sampling. Instrumen pengumpulan data menggunakan skala perilaku kecanduan media sosial. Analisis data menggunakan Uji Wilcoxon yang menunjukkan nilai signifikansi kelompok eksperimen sebesar 0,002 < 0,05, artinya teknik self instruction efektif untuk mereduksi perilaku kecanduan media sosial pada mahasiswa. Penelitian ini merupakan penelitian dasar yang menghasilkan prinsip dasar dari teknologi, formulasi konsep dan aplikasi teknologi, hingga pembuktian konsep penelitian dengan indikator TKT 3.
\end{abstract}

Kata Kunci : perilaku, kecanduan media sosial, self insruction

\section{PEndahuluan}

Globalisasi memberikan perubahan besar bagi kehidupan manusia. Perubahan tersebut terlihat dari perkembangan teknologi yang semakin pesat dalam berbagai bidang. Salah satu hasil kemajuan teknologi yang berdampak pada kebudayaan masyarakat khususnya generasi muda adalah internet (Asmani, 2012:17).
Pengaruh internet sangat besar bagi generasi muda khususnya pada pelajar. Mereka memanfaatkan internet baik untuk mengerjakan tugas sekolah, sarana komunikasi, sumber informasi terkini, eksis ataupun sekedar mengisi waktu luang. Berdasarkan riset yang dilakukan Yahoo (dalam Asmani, 2012:52) enam puluh empat persen pengguna internet di Indonesia adalah remaja usia 15-19 tahun. 
Melalui internet seseorang dapat berkomunikasi dan bertukar berbagai bentuk informasi dari seluruh penjuru dunia. Mudahnya seseorang dalam berkomunikasi saat ini dimanapun dan kapanpun membawa dampak besar dalam kehidupan. Salah satunya penggunaan media sosial yang semakin menjamur dikalangan masyarakat, khususnya kalangan remaja.

Andreas Kaplan dan Michael Haenlein (2010:59) mendefinisikan media sosial sebagai sebuah kelompok aplikasi berbasis internet yang membangun di atas dasar ideologi dan teknologi Web 2.0, dan yang memungkinkan penciptaan dan pertukaran user-generated content. Hampir seluruh manusia diberbagai belahan dunia mengetahui, memahami serta menggunakan media sosial karena kepopulerannya. Facebook, twitter, whatsapp dan instagram adalah beberapa media sosial yang paling aktif dan hampir semua orang menggunakannya. Keberadaan internet khususnya jejaring sosial telah mampu menjadikan dunia sebagai small village (desa kecil) yang melampaui batasbatas jarak dan waktu.

Media sosial dikalangan remaja memang memberikan kemudahan dalam berkomunikasi dan bertukar informasi secara bebas, luas tanpa batasan ruang dan waktu. Namun apabila media sosial digunakan secara berlebihan dan menimbulkan kecanduan akan berdampak negatif bagi perkembangan remaja. Hal ini akan menjadi tantangan besar bagi dunia pendidikan. Peserta didik lebih sering menghabiskan waktunya untuk menggunakan media sosial dan mengakibatkan kecanduan sehingga mereka melupakan tugas utama mereka sebagai pelajar. Media sosial juga membuat peserta didik menjadi malas bersosialisasi dalam dunia nyata dan terlarut dalam dunia maya. Hal ini membuat seseorang yang berjarak dekat dengan kita terasa jauh dan yang jauh menjadi dekat. Terkadang peserta didik menggunakan media sosial hanya untuk mengisi waktu luang, sebagai kesenangan atau sebagai pelarian dari berbagai permasalahan yang dihadapi. Dalam jurnal Waldo (2014:145) yang berjudul Correlates of Internet Addiction among Adolescents, Young dan Rogers menjelaskan bahwa apabila seseorang mengalami masalah, seringkali seseorang menggunakan internet sebagai upaya melarikan diri dengan berkomunikasi melalui internet.

Terdapat klasifikasi mengenai pengguna internet yang mengalami kecanduan, hal ini bisa dilihat dari intensitas penggunaannya. Intensitas penggunaan internet bisa dilihat dari frekuensi dan durasi penggunaannya. Terdapat pada jurnal Waldo (2014:147), Young dan Rogers membagi durasi penggunaan internet menjadi dua yaitu : pengguna internet yang sehat dan yang bermasalah. Pengguna yang sehat adalah pengguna yang mengakses internet sebanyak 8 jam perminggu, sedangkan pengguna internet bermasalah adalah yang menghabiskan waktu mengakses internet sebanyak 38,5 jam perminggu atau sekitar 5 jam perhari. Hal ini juga bisa sebagai acuan untuk melihat 
seberapa tingkat gejala kecanduan menggunakan internet.

Permasalahan kecanduan media sosial ini juga terjadi pada beberapa mahasiswa FKIP Universitas Slamet Riyadi. Berdasarkan observasi yang dilakukan peneliti pada beberapa mahasiswa menunjukkan beberapa gejala perilaku tersebut. Hal tersebut diungkapkan karena setidaknya setiap kelas ada peserta didik yang secara sembunyi-sembunyi menggunakan telepon genggam pada saat kegiatan belajar mengajar sedang berlangsung. Beberapa mahasiswa lebih suka memegang handphone untuk membuka instagram, facebook dan whastapp daripada mengobrol dengan temanteman yang ada disekitarnya. Hal yang terjadi jika siswa terus menerus kecanduan media sosial adalah tidak mengenal waktu, tidak peduli dengan sekitar, kurang sosialisasi dengan lingkungan, mengganggu kesehatan, dan malas belajar. Mahasiswa juga selalu eksis dalam melakukan selfie dimanapun tanpa peduli lingkungan untuk di posting ke media sosial. Tidak jarang postingan-postingan berupa status maupun foto malah menjadi bahan bullying diantara mahasiswa di jejaring sosial.

Alternatif solusi yang bisa dilakukan dalam mereduksi kecanduan media social adalah dengan menggunakan pendekatan secara kognitif dan perilaku, yaitu menggunakan teknik Self Instruction. Self Instruction merupakan salah satu teknik dari pendekatan cognitive behavior therapy, yang melibatkan identifikasi keyakinan-keyakinan disfungsional yang dimiliki seseorang dan mengubahnya menjadi lebih realistis, serta melibatkan teknik-teknik modifikasi perilaku (Bos dkk, 2006). Self instruction memiliki keunggulan, yaitu selain dapat mengganti pandangan negatif individu menjadi positif, metode ini juga dapat mengarahkan individu untuk mengubah kondisi dirinya agar memperoleh konsekuensi yang efektif dari lingkungan. Individu tidak hanya diajak untuk mengubah pandangannya, tetapi juga diarahkan untuk mengubah perilaku yang lebih efektif. Sehingga mahasiswa di ajak untuk mengidentifikasi pemikiran yang salah tentang penyalahgunaan media sosial, akibat dari penggunaan media sosial yang berlebihan, kemudian berfikir secara rasional tentang pemanfaatan media sosial yang tepat. Selanjutnya hasil restrukturisasi kognitif itu di aplikasikan dalam bentuk pengubahan perilaku positif.

Berdasarkan uraian tersebut diatas, penulis tertarik untuk meneliti lebih lanjut tentang pengaruh teknik Self Instruction untuk mereduksi perilaku kecanduan media sosial pada mahasiswa universitas slamet riyadi Surakarta.

\section{METODE PENELITIAN}

Pendekatan yang digunakan di dalam penelitian ini adalah eksperimen. Pendekatan penelitian eksperimen adalah pendekatan penelitian yang menguji apakah variable independent dapat mempengaruhi variabel dependent (Cresswell, 2012). Teknik penelitian eksperimen adalah penelitian yang didalamnya terdapat suatu intervensi dan pengukuran sebelum dan setelah diberikan intervensi. Variabel 
independent di dalam penelitian ini adalah panduan teknik self instruction dan variabel dependent adalah kecanduan media social pada mahasiswa.

Penelitian eksperimen ini menggunakan desain eksperimen "nonequivalent group pretest-postest control design". Desain ini adalah desain yang sudah memenuhi syarat dilakukannya penelitian kuasi eksperimental. Desain ini merupakan desain yang paling fisibel untuk diterapkan dalam setting pendidikan. Peneliti menggunakan kelompok yang sudah ada, memberi pretest, melakukan perlakuan pada kelompok eksperimen, lalu melakukan posttest pada kelompok eksperimen dan kelompok kontrol (Edy Purwanto, 2013 : 117).

Desain penelitian nonequivalent group pretest-postest control design dapat digambarkan sebagai berikut:

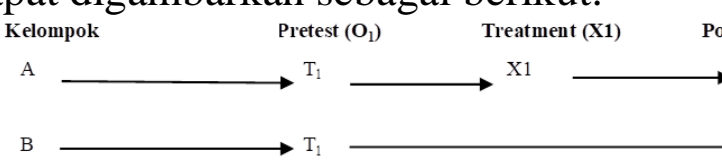

Gambar 1.1 Desain nonequivalent group pretest-postest control design)

Sampel pada penelitian ini berasal dari mahasiswa FKIP UNISRI yang secara purposive random sampling diambil 12 orang sebagai kelompok eksperimen yang akan diberikan treatment self instruction dan 12 orang sebagai kelompok kontrol.

\section{HASIL DAN PEMBAHASAN}

Untuk mengetahui keefektivan layanan konseling kelompok CBT teknik self instruction dalam mereduksi perilaku kecanduan media sosial pada mahasiswa UNISRI maka dilakukan analisis data. Perubahan tersebut diketahui setelah dilakukan pretest dan posttest. Pengujian hipotesis dalam penelitian ini menggunakan statistik nonparametrik teknik Uji Wilcoxon, yang merupakan analisis untuk menguji perbedaan 2 sampel berpasangan. Alasan menggunakan statistik nonparametric adalah karena penelitian menggunakan sampel kecil

Tabel Uji Wilcoxon Signed Ranks Test

Test Statistics $^{\mathrm{a}}$
\begin{tabular}{|r|r|}
\hline $\begin{array}{c}\text { post.kontrol - } \\
\text { pre.kontrol }\end{array}$ & $\begin{array}{c}\text { post.eksperimen - } \\
\text { pre.eksperimen }\end{array}$ \\
\hline$-1.190^{\mathrm{b}}$ & $-3.066^{\mathrm{b}}$ \\
.234 & .002 \\
\hline
\end{tabular}

Tabel diatas menunjukkan hasil uji hipotesis sebagai berikut :

Nilai signifikansi kelompok eksperimen sebesar 0,002 0,05 maka Ho ditolak dan Ha diterima, artinya layanan konseling kelompok CBT teknik self instruction efektif untuk mereduksi perilaku kecanduan media sosial mahasiswa.

Nilai signifikasi kelompok kontrol sebesar 0,234>0,05. Artinya tidak ada perbedaan nilai pretest dan postest, maka tidak terjadi perubahan yang signifikan peningkatan perilaku kecanduan media sosial mahasiswa UNISRI pada kelompok kontrol. Hal ini karena pada kelompok kontrol tidak diberikan perlakuan. Sehingga validitas internal penelitian tetap terjaga, artinya bisa dipastikan bahwa perubahan perilaku kecamduan medsos mahasiswa pada variabel terikat semata-mata adalah akibat dari pemberian treatment. 
Berdasarkan hasil pengujian hipotesis di atas, diketahui bahwa layanan konseling kelompok CBT teknik self instruction efektif untuk mereduksi perilaku kecanduan media sosial mahasiswa.

\section{KESIMPULAN}

Berdasarkan pelaksanaan penelitian tentang efektivitas layanan konseling kelompok CBT teknik self instruction untuk mereduksi perilaku kecanduan media sosial mahasiswa, dapat disimpulkan sebagai berikut:

Hasil penelitian ini menunjukkan peningkatan karakter yang signifikan antara sebelum dan sesudah treatment. Hal ini memberikan bukti nyata bahwa perilaku kecanduan media sosial mampu diturunkan melalui kegiatan layanan konseling kelompok CBT teknik self instruction. Penelitian ini juga memberikan terobosan baru bagi dunia pendidikan mengenai pentingnya penggunaan teknik dalam layanan bimbingan kelompok yang efektif, efisien, ekonomis dan menyenangkan sebagai sarana pendukung dalam mengembangkan berbagai kemampuan siswa.

Teknik self instruction ini, dapat membantu mahasiswa mengubah distorsi-distorsi kognitif tersebut dengan menguji ulang keyakinan mahasiswa dengan berbagai teknik persuasi verbal dan aktivitas yang diberikan secara berulang-ulang sampai mahasiswa mampu melakukannya untuk diri mereka sendiri. teknik selfinstructional yang diterapkan selama kondisi intervensi kepada kelompok eksperimen menunjukkan adanya perubahan perilaku yakni mahasiswa mampu mengelola diri kaitannya dengan intensitas penggunaan media sosial, menunjukkan sikap empati terhadap hubungan sosial secara langsung dan perilaku penggunaan media sosial secara bijak. Hal ini ditunjukkan dengan ikrar janji yang diucapkan dan diterapkan dalam bentuk perilaku nyata, sikap positif dan perilaku penggunaan media sosial secara bijak dikuatkan dengan pemberian self reinforcement yang ditentukan oleh diri masing-masing mahasiswa

Berdasarkan simpulan yang sesuai dengan hasil penelitian, maka dapat diajukan beberapa saran kepada masing-masing pihak sebagai berikut:

1. Bagi Lembaga Pendidikan:

a. Dalam rangka pengembangan kompetensi hidup, peserta didik memerlukan sistem layanan pendidikan di satuan pendidikan yang tidak hanya mengandalkan layanan pembelajaran mata pelajaran/bidang studi dan manajemen, tetapi juga layanan bantuan khusus yang lebih bersifat psiko-edukatif melalui layanan bimbingan dan konseling. Oleh karena itu Lembaga Pendidikan hendaknya memberikan dukungan dan menyediakan akomodasi yang memadai untuk kelancaran pelaksanaan kegiatan bimbingan dan konseling agar dapat berjalan dengan optimal.

2. Bagi Pendidik:

a. Dalam era digital diperlukan layanan pendampingan oleh pendidik kepada peserta didik 
dalam upaya pembentukan sikap dan perilaku penggunaan media internet secara bijak.

b. Pendidik perlu melatih social skill pada peserta didik agar memiliki kemampuan komunikasi interpersonal yang baik dan kepekaan sikap empati dalam bersosialisasi.

c. Hubungan yang baik antara Pendidik dan Peserta Didik merupakan suatu hal yang dapat menjalin kedekatan secara psikologis dalam rangka membantu Peserta Didik mencapai tugas-tugas perkembangannya dan mengatasi masalah secara bersama.

3. Bagi Peneliti Selanjutnya

a. Direkomendasikan bagi peneliti selanjutnya yang melakukan penelitian dengan tema yang sama agar menggunakan desain penelitian yang lebih baik dengan sampel yang lebih luas.)

\section{REFERENSI}

Andreas, Kaplan M., Haenlein Michael 2010. "Users of the world, unite! The challenges and opportunities of social media". Business Horizons 53 (1). p. 61. Asmani, Jamal Ma'mur. (2012). Kiat Mengatasi Kenakalan Remaja Di Sekolah. Yogyakarta : BukuBiru.

Bos, A.E.R, Muris P. Sandra, M. Herman P.S. 2006. Changing Self Esteem in Children and Adolescents: A Roadmap for Future Interventions. Adolescent Development. Annual Reviews of Psychology. 52:83-110.

Creswell, J. W. 2012. Educational Research : Planning, Conducting, and Evaluating Quantitative and Qualitative Research. Boston: Pearson.

Edy Purwanto. 2013. Metode Penelitian Kuantitatif. Semarang : FIP UNNES.

Waldo, A.D. (2014). Correlates of Internet Addiction among Adolescents. Psychology, 5, 1999-2008. Diunduh pada 23 Februari 2015 dari http://dx.doi.org/10.4236/psych. 2014.518203 